\title{
Sticker Emoticons Used in LINE Messenger; A Semantic Study
}

\author{
Ni Luh Nilasari \\ English Department, Faculty of Arts, Udayana University \\ [niluhnilasarii@gmail.com] \\ *Corresponding Author
}

\begin{abstract}
This paper is entitled Sticker Emoticons Used in LINE Messenger; A Semantic Study. This study aims to identify and discuss visual, verbal signs and analyze the meaning and relationship between verbal and visual signs applied of sticker emoticon in the LINE messenger. The reason for choosing sticker emoticons is that they have great visualization that can present the human feelings in sending instant message as a media of communication. The data source was sticker emoticon from LINE group namely "SEVEN'ICHI". In collecting the data, the method used is documentation. The data were taken from the screenshots of the messages using sticker emoticon. The collected data were qualitative analyzed based on the theories applied in this study, namely the theory of semiotics proposed by Saussure, and theory of sign proposed by Peirce. The data were presented in the form of table and description. The result of the analysis shows that there are two types of sticker emoticons found in Line messenger, big and small sizes. The difference of those could be seen from the size in which the big ones are created in the full body size while the small ones are only in the form of the heads.The signs consist of signifier and signified on verbal and visual sign. There were 21 verbal and visual signs found in this study, as well as Representamen, Object and Interpretant. In this study the sticker emoticons in LINE Messenger mean carry, happiness, sadness, satire, mental activities and physical activity. A sign cannot have a totally meaningless signifier or a completely formless signified and it cannot stand alone (Saussure 1983, 101; Saussure 1974, 102-103).
\end{abstract}

Keywords: LINE messenger, Sign, Verbal, Visual, Sticker emoticon

\begin{abstract}
Abstrak
Skripsi ini berjudul "sticker emoticons used in line messenger; a semantic study" penelitian ini bertujuan untuk mengidentifikasi dan mendiskusikan tanda visual dan verbal dan menganalisa makna dan hubungan antara tanda visual dan verbal yang di aplikasikan pada stiker emoji pada line messenger. Stiker emoji dipilih karena memiliki visual yang menarik yang bisa mewakili perasaan manusia dalam mengirim pesan singkat sebagai media komunikasi. Sumber data yang digunakan adalah stiker emoji dari sebuah grup diskusi pada line messenger yang bernama seven'ichi. Dalam mengumpulkan data metode yang digunakan adalah dokumentasi. Data tersebut diambil dari screenshot pesan yang menggunakan stiker emoji. Data yang telah terkumpul dianalisa berdasarkan teori semiotic yang di temukan oleh Ferdinand de Saussure dan teori sign yang ditemukan oleh Charles Sanders Peirce. Data tersebut ditampilkan dalam bentuk tabel dan deskripsi. Hasil analisa dalam penelitian ini menunjukkan terdapat dua buah tipe stiker emoji yang ditemukan pada line messenger yaitu stiker emoji dengan ukuran besar dan kecil. Perbedaan dari kedua tipe tersebut dapat dilihat dari ukuran stiker emoji itu sendiri, yang mana stiker emoji dengan
\end{abstract}


ukuran besar dibentuk dalam ukuran lengkap dari kepala hingga kaki, sementara stiker emoji yang berukuran kecil hanya dalam bentuk kepala. Tanda tanda terdiri dari signifier dan signified pada tanda verbal dan visual. Terdapat 21 tanda verbal dan visual ditemukan pada penelitian ini termasuk representamen, objek, dan interpretant. Dalam penelitian ini makna stiker emoji pada line messenger mengandung makna kebahagiaan, kesedihan, sindiran, aktifitas mental dan aktifitas fisik. Sebuah tanda tidak bisa memiliki signifier yang benar benar tidak memiliki arti atau signified yang benar benar tidak berbentuk dan sebuah tanda tidak dapat berdiri sendiri. (Saussure 1983, 101; Saussure 1974, 102-103).

\section{Kata kunci: LINE messenger, Tanda, Verbal, Visual, Stiker Emoji}

\section{Background of the Study}

Semiotic study is the study of signs and symbols as elements of language or other systems of communication. According to Peirce (Peirce 1931-58, 2.172) anything can be a sign as long as someone interprets it as 'signifying' something - referring to or standing for something other than itself. In semiotic sense, signs can take the form of visual and verbal such as images, objects, words and gestures. As technology develops, visual and verbal sign could also be seen through the application of emoticon in LINE messenger.

LINE messenger is an application that was created by Naver in Japan for instant communication on electronic devices. It can be used to exchange texts, images, video, audios and conduct free VOIP conversation and video conferences.

A popular feature of LINE messenger is its sticker emoticons, in the form of cartoons that can be sent along with messages. A sticker is a detailed illustration of a character that represents an emotion or action emoticons to convey humor or feelings that is a mix of cartoons and Japanese smiley-like "emojis". It contains word as the main element of the stickers to convey the meaning and message while sticker as visual sign offers the communication imagination, and mood. The theory used in this study is theory of semiotics proposed by Saussure, theory of signs by Peirce.

There are several publications done about visual and verbal signs; Sayani (2012) with the study entitled "Semiotic analysis of Memes in 9gag.com", Pidada (2012) entitled "Verbal and Visual Message on Barack Obama Political Cartoons", Reza (2011) entitled "Semiotic analysis of the chatting activity signs (emoticon) on the yahoo messenger for the user"; these previous studies show us anything that contain visual and verbal signs that can be analyzed as a data source.

The readers have to know what are the meaning and relation of each sticker emoticon in LINE messenger, because Sticker emoticon in social media chatting can avoid misunderstanding of the sent message. However, it can also create misunderstanding because the sticker emoticon that has been used is not appropriate in the chatting. This phenomenon makes sticker emoticon in LINE messenger interesting to analyze because of its interesting visual signs and various set of wordings. Sticker emoticon can be easily seen in our smart phone. The data in this study were chosen for sticker emoticon in LINE messenger because they are related to their verbal and visual signs that support this study. From the previous studies there hadn't be sticker emoticon as data for the study, 
most of them prefer to use advertisement, memes, caricature and so on as the data to be analyzed based on the semiotic theory.

Here, sticker emoticons are analyzed in aspect visual and verbal signs, meaning and relationship between visual and verbal sign. The visual and verbal sign of the sticker emoticon is very important because they are related to each other on delivering the meaning of the sticker emoticon in order to obtain the relation between verbal and visual sign and messages of each sticker emoticon.

\section{Problems of the Study}

a) What are signifiers and signified of visual and verbal signs applied of sticker emoticon in the LINE messenger?

b) How are the context supports the meaning and relationship between verbal and visual signs

implied of sticker emoticon in the LINE messenger?

\section{Aims of the Study}

a) To identify signifiers and signified of visual and verbal signs applied in the LINE messenger of sticker emoticon.

b) To analyze the meaning and relationship between verbal and visual signs applied in the LINE messenger of sticker emoticon

\section{Research method}

The research method of this study includes the data source, method and technique of collecting data, method and technique of analyzing data and method and technique of presenting data. Each part of research method is explained as follows:

\subsection{Data source}

The data source used in this study is the sticker emoticons applied in the LINE messenger. This data were taken from the
Group chatting called "SEVEN'ICHI" in LINE messenger. This LINE group was chosen as a source of data because all the members of this group are women and women who said to use sticker emoticon more than men do. Besides, all the members in this group know each other well so they are free to express their feelings or emotion using sticker emoticon as a media communication.

Sticker emoticons in LINE Messenger were chosen as the data source in this study because they are related to their verbal and visual signs that support this study. Sticker emoticons in social media chatting can avoid the misunderstanding of the sent message. However, it can also create misunderstanding because the sticker emoticons that have been used are not appropriate in the chatting; the readers have to know what the meanings and relation of each sticker emoticon applied in LINE messenger.

\subsection{Method and techniques of collecting data}

The data were collected using the documentation method from social media, LINE messenger. Documentation method means that the data were taken from the screenshot of the message using sticker emoticon. Several steps were used in order to collect the data. First, opening the application of LINE messenger and then opening room chat of group "SEVEN'ICHI", and reading all chats. Second, searching the message from the members of group "SEVEN'ICHI" that contained sticker emoticons; then selecting the message which sticker emoticon contained that could be the best representation for the analysis. Then, screen shooting the sticker emoticon already chosen. Lists of the sticker emoticon used as the data were observed carefully in order to obtain better understanding of it. 


\subsection{Method and techniques of analyzing data}

The collected data were analyzed by qualitative and descriptive methods. It means that the data were analyzed by using deep explanation or description without involving measurement or statistics.

There were several steps taken. First, identifying and describing the signifiers and signified of visual and verbal signs applied in sticker emoticons in the LINE messenger based on the Theory of Semiotics proposed by Saussure. Next, analyzing the meaning and relationship between verbal and visual signs implied in sticker emoticons of the LINE messenger based on the theory of sign proposed by Peirce.

\subsection{Method and techniques of presenting analysis}

This study applied formal and informal methods to present the analysis. Formal method means that when the researchers are presenting the result of analysis they use the symbol, table, diagram and number. While informal method means presenting the result of analysis by using words and sentences and its purpose is to give explanation to make the readers understand easily.

In presenting the first problem formal method was applied to present the analysis by using pictures and table. The pictures were presented first then the table; the first table presented verbal sign and next the table presented visual data. The signifier is on the left column and signified is on the right column. Then, informal method was applied in this study for the analysis of the second problem. The analysis was described and explained descriptively in the form of paragraph under the table.

\section{Results and discussions}

There were two types of stickers found in Line, big and small size. The difference of those could be seen from the size in which the big ones are created in the full body size while the small ones are only in the form of the heads. In the analysis below, there are two theories used namely the theory of semiotics by Ferdinand de Saussure and the theory of sign by Peirce. Peirce's sign supports three components which are $\mathbf{R}, \mathbf{O}$ and $\mathbf{I}$. (R) is representamen or something that enters into relation with its object, $(\mathrm{O})$ is object to which the sign refers, and (I) is interpretant which is related to and mediate between representamen and the semiotics object.

According to Saussure (1983:67), a sign consists of a signifier and a signified. Signifier is a form taken by the sign to represent what is being expressed. Signified is an abstract concept of what the signifier represents. The sign is the result of the association between the signifier and signified.

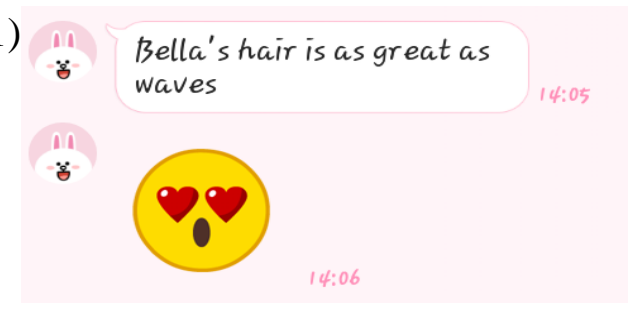

Table of Verbal Sign

\begin{tabular}{|c|c|}
\hline Signifier & Signified \\
\hline $\begin{array}{l}\text { Bella's hair is as } \\
\text { great as wives }\end{array}$ & $\begin{array}{l}\text { The sentence } \\
\text { shows that the user } \\
\text { admires Bella's } \\
\text { hairs that are as } \\
\text { wavy as the wave. } \\
\text { It means, Bella's } \\
\text { hairs are those } \\
\text { types which kind of } \\
\text { wavy yet beautiful. }\end{array}$ \\
\hline
\end{tabular}




\begin{tabular}{|c|c|c|}
\hline \multicolumn{3}{|c|}{ Table of Visual Sign } \\
\hline $\begin{array}{c}\text { Sticker } \\
\text { emoticon }\end{array}$ & Signifier & Signified \\
\hline & $\begin{array}{l}\text { The } \\
\text { emoticon } \\
\text { here is in } \\
\text { the form of } \\
\text { round face } \\
\text { in yellow- } \\
\text { colored in } \\
\text { which the } \\
\text { eyes are } \\
\text { replaced by } \\
\text { the symbols } \\
\text { of heart. }\end{array}$ & $\begin{array}{l}\text { The } \\
\text { symbols of } \\
\text { hearts as the } \\
\text { replacement } \\
\text { of the eyes } \\
\text { show the } \\
\text { expression } \\
\text { of person } \\
\text { who loves } \\
\text { someone or } \\
\text { something. }\end{array}$ \\
\hline
\end{tabular}

$\mathbf{R}$ in the emoticon above brings a symbol of hearts on both eyes which refer to $\mathbf{O}$ falling in love, so that $\mathbf{I}$ implied the user liked Bella's hair.

The sticker emoticon combined with the text produces the whole meaning of the sticker itself. If we pay attention to the sticker emoticon and the text found in data 1; we are able to comprehend the meaning behind the sticker emoticon. The sticker emoticon above brings a symbol of hearts on both eyes which refer to falling in love with something. As we can see the sentence Bella's hair is as great as waves; it is something more than the dictionary meaning. It does not show the literal meaning of the sentence itself. This sentence refers to the waves as the symbol of beauty to the figure of Bella's hair.

According to triadic models by Peirce, the meaning of the sticker emoticon above can be seen from the relation between $\mathrm{R}$ (representamen), $\mathrm{O}$ (object), and I (Interpretant), so we can conclude sticker emoticon 1 has the meaning that the expression of the user who liked Bella's hair.
The verbal and visual signs in the data above are related to each other; a sign cannot have a totally meaningless signifier or a completely formless signified and it cannot stand alone. If we can see from the text it shows that the user praises Bella's hair but after putting the sticker emoticon, the meaning is different, it indicates that the user really likes Bella's hair.

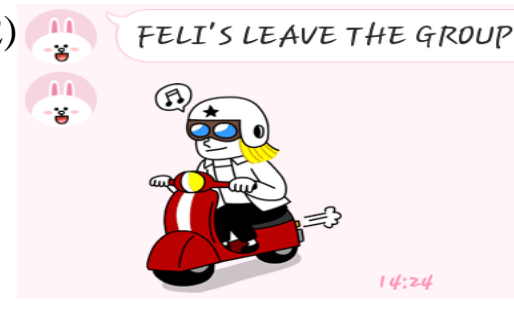

Table of Verbal Sign

\begin{tabular}{ll}
\hline \multicolumn{1}{c}{ Signifier } & \multicolumn{1}{c}{ Signified } \\
\hline FELI'S LEAVE & This sentence \\
THE GROUP & $\begin{array}{l}\text { shows that the user } \\
\text { wants to leave the } \\
\text { conversation so she } \\
\text { leaves the group }\end{array}$ \\
\hline
\end{tabular}

Table of Visual Sign

\begin{tabular}{ccc}
\hline $\begin{array}{c}\text { Sticker } \\
\text { emoticon }\end{array}$ & Signifier & Signified \\
\end{tabular}

This sticker is This is the
in the form of a symbol of
man that rides a someone
motorcycle in who is
red colored, and traveling.
used the helmet.
There is the
melody icon
beside the head.

$\mathbf{R}$ in the sticker above brings the icon of a man and also a motorcycle that refer to $(\mathbf{O})$ riding a motorcycle, so $(\mathbf{I})$ in 
the sticker above shows that the user wants to leave from the conversation being held in the group. As we can see the sentence "Feli leave the group" refers to something that has a hidden meaning, because if we just look at the sentence it means that Feli leaves the group she joins. But the real meaning of this sentence is a joke from the user illustrated with the sticker emoticon itself. From the sticker emoticon it refers to someone who has riding a motorcycle. From the verbal sign, this sticker emoticon has the meaning of run-away because it contains the icon of motorcycle which illustrates appliance transportation for run away.

The verbal and visual signs in the data above are related to each other. The verbal sign explains the visual sign in which the user wants to leave from the conversation that being held in the group chatting, she uses this sticker emoticon to express her feeling. Without verbal sign the visual sign here will have different meaning; it is based on the verbal sign it self. A sign cannot have a totally meaningless signifier or a completely formless signified and it cannot stand alone.

\section{Conclusions}

There are some points that can be concluded based on the analysis of the previous chapters. In LINE messenger there are two types of sticker emoticons found in LINE messenger, big and small sizes. The difference of those could be seen from the size in which the big ones are created in the full body size while the small ones are only in the form of the heads.

There are twenty one verbal and visual signs of sticker emoticon found in group LINE namely "SEVEN'ICHI" in LINE messenger, each of them consists of signifier and signified. After seeing the relationship between Representamen,
Object and the Interpretant in general the meaning of sticker emoticon implied in LINE messenger are, happiness, sadness , satire, mental activities and physical activity. The sticker emoticons that are frequently used in LINE messenger are, smile, sad, happy, laugh, cry, sick, tired, sleepy, shock, angry, kissing and hug.

Verbal sign is something which deals with text and words, while visual sign as pictures present the point of products, logo company etc. in matter of visual sign. The sticker emoticon in LINE Messenger has a good combination between the verbal and visual sign. In term of verbal sign, the sticker emoticon consists of some written texts (phrase and sentence), which are considered beneficial in conveying the meaning of the sticker emoticon. Thus sign supports each other to attract the audience's attention by presenting their interesting unity.

The relationship between Verbal and Visual sign found in LINE Messenger of Sticker emoticons are related to each other. A sign cannot have a totally meaningless signifier or a completely formless signified and it cannot stand alone. Each sticker emoticons in LINE Messenger have a different function according to the sticker emoticon itself.

\section{References}

Chandler, Daniel.(2001) Semiotic for Beginners.

Available at: http://visualmemory.co.uk/daniel/ Documents/S4B/sem02.html.

Cobley, Paul. (2001). The Routledge Companion To Semiotics And Linguistics. London: Routledge (Taylor \& Francis Group). Available from: http://faculty.georgetown.edu/irvi nem/theory/Merrell-Pierce-onsign- Routledge.pdf. 
Peirce, C.S. (1986). Logic as

Semiotic:The Theory of Signs.

InSemiotics:An Introductory

Reader.Ed.R.E. London : Innis,

Hutchinson.

Peirce, C.S. (2009). Peirce's Theory of

Sign. Cambridge: University

Press.

Saussure, Ferdinand de, Barthes,

Bakhtin. (2001). City of

Chandler. Available at:

http://www.learning-

theories.com/semiotics-de-

saussure-barthes-bakhtin.html.

Saussure, Ferdinand de. (1983). Theory

of Signified and

Signifier.McGraw-Hill Book

Company. Geneva. 